\title{
Different Interests Explain Different Proposals: The Contestation of Indo-Pacific Cooperation Framework between ASEAN and the US
}

\author{
Sri Yunanto \& Galby Rifqi Samhudi \\ Universitas Muhammadiyah Jakarta \& Universitas Indonesia
}

\begin{abstract}
The rise of China that goes along with strategic shifts around the Indian and the Pacific Ocean has started a new stage of major power contestation recently. ASEAN which acts as a host in Southeast Asia has certain stands to deal with the challenges and opportunities presented by the competition. On the other hand, the US Government with its global interests will never ever allow this region to fall into China's influence. Simultaneously, both ASEAN and the US have the same approach in this situation to utilize the framework of Indo-Pacific cooperation that is definitively open to any explication in order to gain advantages resulted from the global interaction over the region. Nevertheless, their perceptions on the matter of defining the cooperative framework of Indo-Pacific are apparently diverse. Hence, this paper attempts to analyze the rationale of ASEAN and the US development of the Indo-Pacific cooperative concept based on their respective strategic assessment. This paper argues that the distinctive interests and insight of threats from ASEAN and the US toward the rise of China as well as major power contestation in the region are being the two main factors in their different perceptions on the concept of Indo-Pacific cooperative framework.
\end{abstract}

Keywords: ASEAN, Indo-Pacific, the US, regional strategic assessment

Kemuculan Tiongkok yang berbarengan dengan pergeseran strategis yang terjadi di sekitar Samudera Pasifik dan Samudera Hindia telah membuka lembaran baru bagi kontestasi negara kuat baru-baru ini. ASEAN yang menjadi tuan rumah di Asia Tenggara memiliki pendirian tersendiri untuk menghadapi tantangan dan peluang yang dibawa oleh kontestasi tersebut. Di lain pihak, Pemerintah Amerika Serikat yang memiliki kepentingan global tidak akan pernah membiarkan wilayah ini jatuh ke pengaruh Tiongkok. Secara berkelanjutan, baik ASEAN maupun Amerika sama-sama memiliki pendekatan yang sama pada situasi ini dengan memanfaatkan pengembangan konsepsi kerangka kerja sama Indo-Pasifik yang terbuka bagi berbagai penjabaran untuk mendapatkan keuntungan sebanyak-banyaknya dari interaksi global yang melalui wilayah ini. Akan tetapi, persepsi keduanya akan definisi kerangka kerja sama Indo-Pasifik berbeda. Oleh karena itu, artikel ini mencoba untuk menganalisis alasan ASEAN dan Amerika mengembangkan konsepsi kerja sama Indo-Pasifik yang didasari oleh penilaian strategis masing-masing kubu. Artikel ini berargumen bahwa perbedaan kepentingan dan persepsi ancaman bagi ASEAN dan Amerika akan kemunculan Tiongkok dan juga kontestasi negara kuat pada wilayah ini merupakan dua alasan utama mengapa mereka memiliki persepsi yang berbeda akan konsepsi kerangka kerja sama IndoPasifik.

Kata-kata Kunci: ASEAN, Indo-Pasifik, Amerika, Penilaian strategis kewilayahan 
The term of Indo-Pacific, which mainly refers to the region around the Indian as well as Pacific Oceans, has had its early development in the first decade of the $21^{\text {st }}$ century and continuously receives greater attention in the following decennary involving various actors in the global sphere. Gurpreet Singh Khurana claimed that he was the first one introducing the terminology on academic discourses through his work entitled "Security of Sealines: Prospects for India-Japan Cooperation" and published by Strategic Analyses Journal of the Institute for Defense Studies and Analyses (IDSA) in January 2007. According to Khurana, the term of Indo-Pacific has been an open concept used by several countries having for numerous interests (2017). On the other hand, Japanese Prime Minister Shinzo Abe is believed as the first world leader who brought up the concept as a cooperative framework when he was delivering a speech to the Indian parliament in 2007 (Suryadinata 2018). In the Japanese point of view, the cooperation scheme under Indo-Pacific architecture refers to an attempt of cooperation between countries around Asia, Africa, Pacific, as well as Indian Oceans which values freedom, the rule of law, the market economy, free from force or coercion, and prosperity under Japan's responsibility (Kelkar 2018). Those initiatives of developing the term of Indo-Pacific receive more notable concern in the second decade of the $21^{\text {st }}$ century when the rise of China through One Belt One Road (OBOR) clashing with the existing US and its allies' interests around the region of the Indian as well as Pacific Oceans. Of those interests are Proliferation Security Initiative (PSI) which launched in 2004 (Kuo 2018) and international freedom of navigation. The existence of influence exchange in security-related issues around Indo-Pacific became more apparent when China continuously developed suspected-military base on the disputed island of Spartly despite protests from the Philippines and Vietnam which are among the claimant states of the SCS conflict (Phillips 2018). Wrapping up the relations between the term of Indo-Pacific cooperation framework and the reality on the ground, it is an appealing discussion for global actors to always address their awareness to the current condition in the region seeing any happenings would be substantial for the upcoming strategic policies.

As the consequence of Indo-Pacific mental map that refers to the area around Indian and Pacific Oceans, Association of Southeast Asian Nations (ASEAN) inevitably has to bear its own stand on the matter of Indo-Pacific cooperative framework. The area of Indo-Pacific is stretched out along the Indian Ocean Region to the Western Pacific Region (Khurana 2017), which is also called by the maritime underbelly of Asia (Kuo 2018). In other words, it involves a huge number of countries including major powers in world politics such as China, Russia, Japan, India, and Australia. For ASEAN itself, it is only Laos which is considered a land lock country while the other nine ASEAN members enjoy maritime rich resources blessing. Consequently, even though major powers interplay is considered indispensable to the regional dynamics, ASEAN states which locally host important sphere of Indo-Pacific also partake important share in the discussion. Even though ASEAN member-countries have not united their voice yet on the matter of developing Indo-Pacific cooperation framework, there still are claims from its members that buck-pass ASEAN platform in so many ways. Indonesia is one of those countries that is actively engaged in Indo-Pacific cooperative initiatives and, at the same time, gives a shot to embrace other fellow ASEAN countries to unite their understandings on the matter.

The rise of China has been in conformity of some security as well as some economic threats to some countries in the region around the Indian as well as the Pacific Ocean 
and to the current global main actors, such as the US and its allies. One of the apparent instances of the security threat is the escalation of the South China Sea (SCS) conflict. Throughout its nine-dash-line claim which sharpens the dispute between its and those Southeast Asian countries such as Brunei, Malaysia, the Philippines, and Vietnam over Paracel, Spratly, and some maritime territories (BBC 2016). The security threat possessed by the Chinese maneuver did not stop around the region since it spreads globally instead as its grand strategy is to secure its maritime road by introducing OBOR and Belt Road Initiatives (BRI) later on. According to a report from the Pentagon (2018 in Ng 2018), Chinese military "has rapidly expanded its overwater bomber operating areas, gaining experience in critical maritime regions and likely training for strikes against US and allied targets". Besides the security threat, the rising of China also contains an economic threat to the US and its allies as China had paid USD 23 million in funding port facilities in Bulgaria, provided USD 3.8 billion in financing high-speed railroad between Hungary-Serbia, and acquired a German robotic company employing 14.00o people worldwide (Ewing 2018). This action rings the bell for the US and its allies in the region of Indo-Pacific, such as Australia, Japan, South Korea, and Taiwan, to maintain their interests as well as domination in the region.

As the result of the rise of China and Indo-Pacific region's importance to global politics, regional major actors, such as ASEAN and the US, should set particular stands on the matter of cooperative framework for the contested region. This has to be done to maintain stability and cooperative relations among the countries involved in the midst of existing competition. In fact, the cooperative architecture of Indo-Pacific used by both parties has dissimilarities in substantial ways. Hence, this paper aims to answer why ASEAN and the US have different proposals on the cooperative framework of Indo-Pacific out of similar geographical location.

\section{Theoritical Framework}

Out of various alternatives that can be taken by states when they encounter external substantial threats, at least there are two opposite options that are available, balancing and hedging. Both are highly considered when there is a revisionist state challenging the status quo which can be a threat to certain countries and an opportunity to others. According to Walt (1987), states choose to take balancing against the threat for two key reasons, which are; (1) their survival at risk if they fail to curb a potential hegemon before it becomes too strong; and (2) joining the weaker side to increase the new member's influence within the alliance, because the weaker side has a greater need for assistance. The form of balancing, according to Mowle and Sacko (2007), can be matching, exceeding, and blocking the targeted state so it does not vanquish the status quo. According to Tziampiris (2015), the very subject of balancing is the power of the state, especially military power, and its distribution in the international system. There are four factors that are decisive to the initiation of balancing which are aggregate power, geographic proximity, offensive power, and aggressive intention (Walt 1987). Considering the geographic proximity, hence, the hypothesis of balancing is not necessarily to be always at the global level, but it also can be applied in the regional level (Art 2005/2006). It is not necessarily one single state struggles for balancing attempt all the way by its own. According to Tziampiris (2015), the discussion between Waltz 
(1979), Mearsheimer (2001), Lieber and Alexander (2005), and Platias and Kolipoulos (2010) reveals that there are two kinds of balancing which are internal and external balancing. Internal balancing refers to internal attempt of the state to strengthen its diplomatic, military, economy, political, and cultural sectors while external balancing refers to forming alliances or cooperation with at least one state on a variety of levels.

In this paper, the status quo in which the US is regarded as the hegemon state is considered experiencing a dynamic of competition between the US and China, as a revisionist state. That competition does not apply in the international stage only, but also in regional of Indo-Pacific realm in which before the emergence of China, it enjoyed equilibrium situation under US hegemony. The main reason for the US to take a balancing approach against China is that their domination has been challenged by the offensive emerging power of China. To stop China's approach in spreading its influence throughout the region, the US attempts to match the activity of embracing ASEAN countries as potential partners of cooperation (not alliance as what the theory hypotheses), to exceed advantages if ASEAN countries are willing to join its initiative, and to block any possible agreement that China could make with ASEAN counterparts. The step taken by the US to balance against China is through the development of IndoPacific cooperative architecture.

The aggregate of power that China has been developing seems promising to be progressing day by day. Moreover, the geographic proximity of China to US close allies such as South Korea, Japan, and Australia becomes the next key consideration to the US to take up China seriously. Besides, China's unwillingness to follow the US approach to the region worsens Chinese image to the US as it does not happen to other US friends in the region. Hence, external balancing in the form of recalling cooperation under the Indo-Pacific platform is taken by the US to balance Chinese maneuver in spreading influence on countries in the Indo-Pacific region, especially those of ASEAN.

On the other hand, hedging, as a part of the balance of power theory (Koga 2018), becomes another alternative that can be taken by states facing an emerging state in either international or regional realm. The term hedging refers to an act done by states, which are usually categorized in secondary power (Salman and Geeraerts 2013), when they spread the risk in approaching two opposing parties in a highly uncertain situation in which if one fails them, the other would compensate the loss. Lake (1996) simply defines it as an insurance policy against opportunism. Similarly, with the balance of power which high-holds the supremacy of national interests as the key to driving force of the state in the anarchic environment (Nexon 2009), there are things to be considered in hedging attempt. According to Kuik and Rozman (2015), there are two circumstances lead states to hedging; (1) when there is a high stake involved; and (2) when there is a high level of uncertainty. In other words, the higher the uncertainty, the higher the possibility to states to do hedge. In contrast with balancing, hedging is not meant to fight head-to-head the rising state having the intention to revise the status quo. Hedging is utilized by countries, that know their limited ability to compete, from both sides of the revisionist state and the status quo holder. In case of either one prejudices them, the other one would redeem anything that can be saved, so their loss could be minimized.

In the case of ASEAN in dealing with the US-China contestation of power over the 
region of Indo-Pacific, hedging has been utilized by the regional organization to apply a safer approach. The Indo-Pacific cooperative architecture is aimed at inviting any parties, including both contesting states, to join inclusive collaboration in numerous sectors. The alternative of making an open framework is based on a regional assessment of uncertainties impacted by the tension. In the same time, the dispute of the major powers also opens the gate of opportunities for ASEAN countries in many ways. Hence, it can be observed that the rationale of hedging by ASEAN comes from that high uncertainty that could be turned into either negative or positive communal consequence for ASEAN member-states.

While the international system is wide open, the possibilities of states to use either approach of the balance of power or hedging at the same time are obviously possible. Hence, this paper intends to utilize both approaches in explaining the dissimilarities between ASEAN and the US in developing the concept of Indo-Pacific cooperation framework. While the existing literature has paid so much attention to how countries around the world use both approaches in different circumstances and time, this paper aims to collaborate them in one single situation and period of time. In this paper, the way of ASEAN shapes Indo-Pacific cooperative framework is explained with a hedging approach, whereas that of the US is illustrated with the balance of power one.

\section{The Emergence of China and The Clash of Interests}

The solid domestic economy has been important to China's basis of spreading its influence by outflowing Foreign Direct Investment (FDI) worldwide. With the basis of mixed economy incorporating limited capitalism within a command economy, China's economy has enjoyed 30 years of explosive growth. Its GDP's growth has been in a steady trend when it reached $7.8 \%$ in 2013, 7.3\% (2014), 6.9\% (2015), 6.7\% (2016) (Amadeo 2019), and 6.9 (2017) (Trading Economics 2019). As a result, China has successfully lifted more than 800 million of its people out of poverty and, reached as well as contributed to Millenium Development Goals (MDGs) globally (The World Bank 2018). Since 2010 to 2017, the trend of outflow investment from China had been in positive growth except in 2017 when it only reached USD 101 million after it peaked in the previous year with USD 216 million (OECD 2019). Foreign investment by China flows around the world including Asia, Africa, and North America. The vision of global FDI, which addresses to financing infrastructure projects, was later on solidified in form of the Asian Infrastructure Investment Bank (AIIB) established in 2016 and has 93 approved members worldwide (AIIB 2019).

According to CSIS, Southeast Asian countries received 29.5\% of Chinese FDI to the continent of Asia-Oceania in 2005-2017 while African countries enjoyed considerable fluctuation of FDI amount as a result of the global financial crisis. Nevertheless, Chinese FDI (USD 40 billion) held the four largest FDI in Africa after that of the US (57 billion), the UK ( 55 billion), and France (49 billion) in 2016. On the other hand, Europe and North America (excluding Mexico) have become major destinations for Chinese FDI in the period of $2005-2017$ with $52.1 \%$ of Chinese total global FDI outflows. In the same time frame, the US has been the first largest recipient country for Chinese FDI and followed by Australia (CSIS 2019a). In other words, China's global economic 
development has been enjoyed by numerous countries including big ones right after she successfully developed its economy at home.

Besides economic leverage, China also has developed its trade network within and without the continent utilizing international sea trade lines. In the second decade of the $21^{\text {st }}$ century, Chinese exported goods had a positive fashion despite slight diminution in 2016 with around USD 2 billion lower compared to the amount of the previous year. Nevertheless, the value of Chinese exported goods increased again in 2017 with around USD 2 billion more which value USD 2.26 trillion. That number was only been beaten by the highest accomplishment in 2014 with USD 2.34 trillion within the period of 2010-2017 (Statista 2019). On the other hand, the US goods import in the same time frame only reached USD 1.62 trillion as of the biggest achievement, in the same year when China did so and fell to the lowest point in 2010 with USD 1.27 trillion (Statista 2019). That number of the lowest US imported goods was still too small compared to that of China with USD 1.57 trillion which took place also in 2010 (Statista 2019). Those numbers reflect the crowd traffic of maritime-based global trade which one-third of it passed the South China Sea (UNCTAD 2016). The decent amount of ship traffic in the area of the SCS took place because it connects the Indian Ocean and the Pacific Ocean. 2016 data shows that China had the biggest share of South China Sea trade compared to any other individual countries on earth with $21.9 \%$ (while the US only shared $3.09 \%$ and the five major countries in ASEAN shared around 21\% combined) (CSIS 2019b). Those phenomena show that China has been becoming a major player in international trade utilizing sea lane altogether with old global country traders such as the US.

In order to ensure those important sea trade lines, China has initiated a marine security strategy and developed naval facilities in a number of important watery areas. NineDash-Line (NDL), One-Belt-One-Road (OBOR), and Belt Road Initiatives (BRI) are among the strategies undergone by China to promote economic integration (Hou et al. 2018) and to connect the global economy (Yan 2018). The most apparent action taken by the Chinese government is the militarization of the waterway around Spratly archipelago (Phillips 2018) which, according to a Chinese naval officer, was built for mainly civilian purposes, and that could be upgraded to military ones if China feels threatened (Bodeen 2019). This circumstance has risen the concern of a number of countries that are threatened directly as their territories are partly claimed unilaterally by China. The countries are Brunei, Malaysia, the Philippines, and Vietnam, which the latest two shown the intense negation as the Philippines brought the case to the international tribunal in The Hague (Phillips et al. 2016). Nevertheless, China rejected the decision and called it "a piece of paper that is destined to come to naught" (Phillips 2016). In other words, no matter objections showed by other countries, Chinese intention to gain strong maritime security mechanism is unmoved away.

The rise of China has been in conformity of some security as well as some economic threats to some countries in the region around the Indian as well as the Pacific Ocean and to the current global main actors, such as the US and its allies. One of the apparent instances of the security threat is the escalation of the South China Sea (SCS) conflict. The dispute is reportedly involving China and Southeast Asian countries such as Brunei, Malaysia, the Philippines, and Vietnam. Throughout its nine-dash-line claim which sharpens the dispute between its and those Southeast Asian countries mentioned over Paracel, Spratly, and some maritime territories (BBC 2016). The security threat possessed by the Chinese maneuver did not stop around the region 
since it spreads globally instead as its grand strategy is to secure its maritime road by introducing OBOR and Belt Road Initiatives (BRI) later on. According to a report from the Pentagon (2018 cited in Ng 2018), Chinese military "has rapidly expanded its overwater bomber operating areas, gaining experience in critical maritime regions and likely training for strikes against US and allied targets”. In addition to the security threat created by China, it also contains an economic threat to the US and its allies. European countries which many of them are the allies to the US are disturbed by China economic expansion in the continent as, for example, China had paid USD 23 million in funding port facilities in Bulgaria, provided USD 3.8 billion in financing high-speed railroad between Hungary-Serbia, and acquired a German robotic company employing 14.00o people worldwide (Ewing 2018). This action rings the bell for the US and its allies in the region of Indo-Pacific, such as Australia, Japan, South Korea, and Taiwan, to maintain their interests as well as domination in the region.

\section{ASEAN and The US Conceptualization of Indo-Pacific for Regional Coop- erative Framework}

The action of China by initiating BRI has invited a number of different reactions, especially from ASEAN and the US which is reflected in dissimilarities of the IndoPacific cooperative framework. The US whose concerns in the region of Indo-Pacific as part of its global leadership has a view on the matter of Indo-Pacific cooperation initiative. The US Vice President, Mike Pence, insisted Asian nations get on board with Washington's Indo-Pacific strategy which is backed by Australia and Japan (Laksmana 2018a). The concept of Indo-Pacific by the US and its allies contains strategies serving the countries around the region such as economic, political-security affairs, and culture (Steward 2018). The strategy is in line with the criteria of balancing as China is being the targeted revisionist state to the status quo. On the other hand, ASEAN has set up its own definition of Indo-Pacific cooperation architecture that is in line with its regional norms recognized also by extra-regional partners. Here, the initiative done by ASEAN is considered a hedging approach to the contestation of power in the region between the US and China.

Apparently, Washington has shown its intention to keep the Indo-Pacific cooperation framework as an 'open' and 'free' region, but it has been doubted by many as it also indicates countermeasure to China. Rex Tillerson speech on US-India relations is believed as an early US conceptualization of Indo-Pacific initiative before President Trump brought it up once again in Asia Pacific Economic Cooperation (APEC) CEO Summit in Vietnam. The term 'Indo-Pacific Dream' was coined by President Trump to depicture his vision on a free and open Indo-Pacific which excludes no nation, as Mike Pence added later on (Samaan 2019). Nevertheless, with all promises following its Indo-Pacific nomenclature, the US seems to develop it as its response to the China expansion of politico-military activities from the Western Pacific to the India Ocean. Pence said in 2018 East Asia Summit (EAS), "We all agree that empire and aggression have no place in the Indo-Pacific" (2018 as cited in Garekar 2018). This speech came after his major address in Washington in which he spoke contrary to China's aggression around East as well as South China Seas and criticized its use of so-called 'dept diplomacy'. This accusation is based on the fact that China expanded its influence 
over the smaller nations in Asia continent by giving them unsustainable infrastructure loans (Garekar 2018) even though James Mattis also said that the US does not "ask any country to choose between the US and China" (Samaan 2019). Besides that accusation against China, the US National Security Strategy (2017) under Trump's presidency also explicitly states that "China seeks to displace the US in the Indo-Pacific region, expand the reaches of its state-driven economic model, and reorder the region in its favor". That statement was later on followed by the rebranding of the symbolic of US Pacific Command into the Indo-Pacific Command (Samaan 2019).

The US response to the emergence of China by purposing a motion of regional architecture of Indo-Pacific is considered the conduct of balancing. The anarchic international system that is believed by many to be a unipolar as the US dominates global politics with its resources in economic as well as military created the framework that the world now is in balance under the US hegemony. However, that notion's relevance has been rivaled by the offensive emergence of China that developed its national capability at home and then expanded it overseas continuously. In fact, many countries in Northeast Asia such as Japan and South Korea show progressive development to become developed countries too. However, unlike Japan and South Korea, China did not show any intention to make allies with the US and its traditional allies. Thus, Chinese global rising power is considered a threat to the US and needed to be balanced against by any means necessary in practicing the image as hegemon of the US to invite countries around the strategic area of Southeast Asia, where secondary countries are located, not to fulfill the invitation of China. The attempt such as Pence's accusation of 'dept diplomacy' of China, as discussed previously, serves as one sort of balancings which means blocking China from accumulating power through initiating strategic agreements with ASEAN member-states. In addition, having Japan and Australia within Indo-Pacific cooperative architecture is also seen as power accumulation as well as external balancing for US favor to encounter the threat from China and to invite more possible counterparts from ASEAN. In doing so, the US seems to utilize some appealing values equipped to its cooperation initiative of Indo-Pacific such as free and open Indo-Pacific that is closely related to the non-intervention norm of ASEAN.

What the US under Trump's administration has been working for in the form of balancing is actually nothing new compared to his predecessors' policy to the region; as a matter of fact, his commitment to the Indo-Pacific region's well-being remains doubtful. Under both President George W. Bush Jr. and President Obama, Indo-Pacific initiative had been US foreign policy focus based on some strategic reasons. The former drove the country to get closer with India for his efforts of military expansion and nuclear cooperation agreement in 2005 while the later used it as 'pivot' or 'rebalance' strategy (Samaan 2019) to get closer with US competitors and allies in Asia (Cha 2016). Recently, President Trump has proposed USD 1 billion funding for free and open IndoPacific as part of his USD 4.7 trillion of 2020 budgetary proposals to the Congress. That budget is aiming to support democracy, good economic government, private sector mobilization and competitiveness, infrastructure, and security cooperation (Jha 2019). Nevertheless, Trump's campaign on 'America First' which directs his foreign policy to more America-centrism has raised doubt of many of its global allies, especially on the matter of Indo-Pacific regional affairs. That hesitancy was finally proven when Trump skipped two important meetings in 2018 of 18-Nation Summit held by ASEAN and APEC Summit which was normally attended by 21 leaders, including Chinese Presiden 
Xi Jin Ping and Russi a’s Vladimir Putin (Gallu and Tweed 2018).

On ASEAN side, the Foreign Affairs Ministerial Meeting by January 2018 and the $13^{\text {th }}$ EAS taking place in November 2018 have become the important theater of observation since countries involved in Indo-Pacific cooperation initiative conception met and discussed it with their counterparts. Indonesia as a reputable active member was notably seen to promote the idea of 'Indo-Pacific Outlook' to other ASEAN memberstates. Through its Minister of Foreign Affairs, Retno Marsudi, Indonesia promotes Indo-Pacific cooperation architecture which includes dialogue promotion and ASEAN's unity in addressing international as well as regional issues (Nathalia 2018). 'Indo-Pacific Outlook' concept paper, that was circulated among ASEAN members, has been formulated with inclusion mind and has emphasized common interests such as development and prosperity (Laksmana 2018b), instead of values such as democracy as what purposed by the US and Australia (Saiman and Bayuni 2018). That type of difference about openness in political value creates difference among ASEAN memberstates which abide different ideology in running their states. Hence, when there is a limited value applied by the US within its Indo-Pacific cooperative architecture, ASEAN states prefer not to be limited in this way. As a result, the initiative of Indonesia on IndoPacific Outlook seems to be implemented in the near future as Jose Antonio Morato Tavares, the Director General of ASEAN Cooperation of Ministry of Foreign Affairs of Indonesia, said, "There were no signs of rejection to the Indo-Pacific concept from the heads of state and government attending the $13^{\text {th }}$ Summit Meeting of East Asia" (2018 as cited in Kurmala and Prasetyo 2018). All in all, ASEAN wants it to be based on typical ASEAN key principles such as ASEAN centrality, openness, transparency, inclusivity, and a rules-based regional architecture (Laksmana 2018b).

ASEAN seems to develop the concept of Indo-Pacific as an open channel of cooperation with no superpower being the center of agenda-setter and substantial interests being the main driver of any collaboration under the Indo-Pacific framework. The range of countries conterminous to the Indo-Pacific area, especially those under the ASEAN platform, is varied in term of their respective economic capacity as well as strategic perspective. Gross Domestic Product (GDP) per capita difference by the US and Singapore in 2017 was admittedly not so measurable with USD 59.792 (Statista 2018) and 57.713 respectively. However, if that of Singapore is compared to that of the rest of the ASEAN countries, the gap was so apparent. With the lowest GDP per capita of the country in the region, Myanmar's GDP per capita was only USD 1.278 in 2017. As the lowest achiever, Myanmar was followed by Cambodia (USD 1.379), Vietnam (2.353), and Laos (2.540). The size and population obviously do not ensure convincing economic posture since Indonesia as the largest of all in them within both measurements only positioned in the fifth after Singapore, Brunei (USD 28.278), Malaysia (9.755), and Thailand (6.590) (Statista 2018). Considering those differences, ASEAN has to find a way to accumulate alternatives, so its member-states are able to take advantage of the existence of ASEAN as a regional organization.

The emergence of China is seen as an opportunity to ASEAN as a unit to gathering as much as advantages for its member-states. In the midst of searching FDI or another form of foreign investment, the US government under President Trump has implemented a much protective policy to secure and to maximize the US profit from international interaction instead of providing easy assistance to its counterparts. As a result, ASEAN countries have to find another way to fulfill their needs from foreign aid or FDI. Indonesia 
as the regional leader (Putra 2015) puts some effort to create a mutual understanding of the current issue by combining it with the importance of regional integration under the ASEAN platform. Steady economic development and international trade of China are two attractive factors for ASEAN to keep good relations as Chinese FDI throughout AIIB which would fund ASEAN states infrastructure projects. In addition, unlike what the US purposed, the Chinese government that does not concern about the ideology, such as democracy, as well as the political-governmental system of ASEAN countries so offers from China seems more appealing to non-democratic countries in Southeast Asia. Figure 1 clearly shows that Chinese FDI to ASEAN countries has been mounting up on an annual basis from 2007-2015.

\section{Figure 1. Chinese Foreign Direct Investment in Southeast Asian Countries}

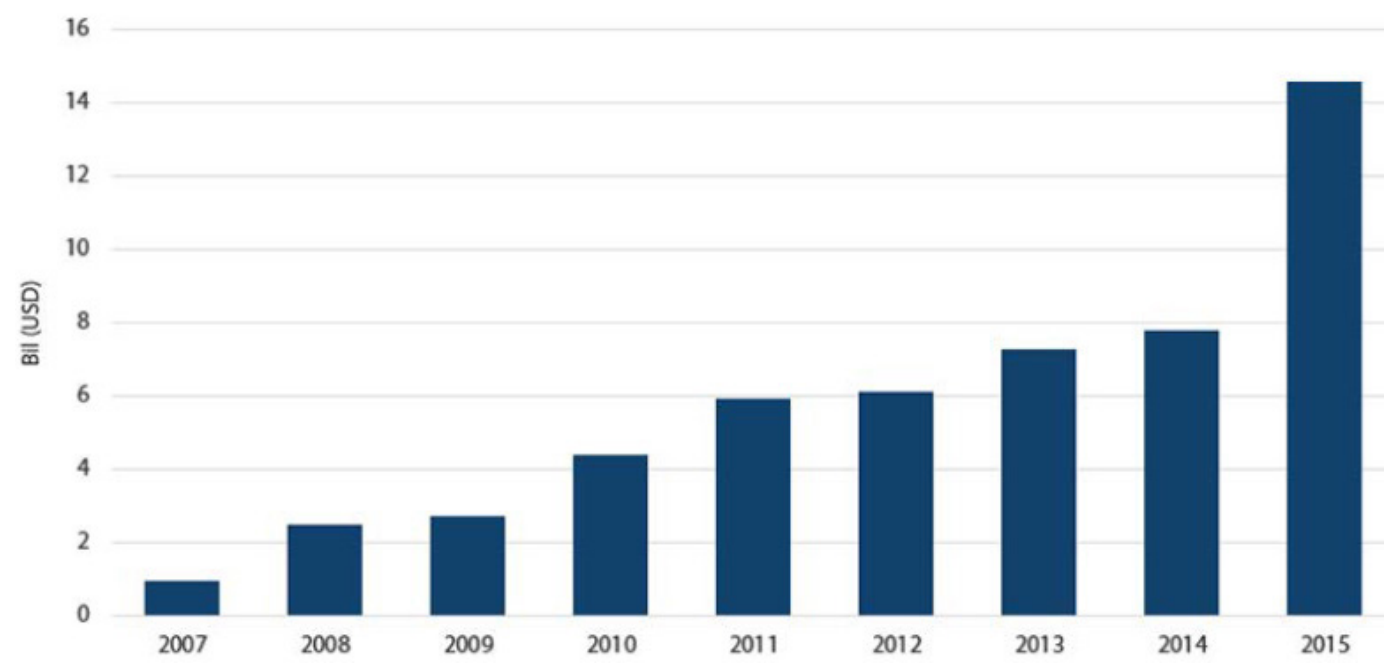

Source: WIND 2017 as cited in Ng 2017

Besides practical reasons in the pillar of Indo-Pacific conceptualization by ASEAN, there are also principals dimension that drive ASEAN perception on the matter. The norms such as openness, transparency, ASEAN centrality, and rules-based regional architecture are common norms in all ASEAN agreements. Some important ASEAN's cooperative frameworks have highlighted the importance of those norms as they are mentioned in the ASEAN Charter, ASEAN Economic Community Blueprint, ASEAN Political-Security Community Blueprint, and ASEAN Socio-Cultural Blueprint. Those documents are considered as ASEAN attempt to achieve their regional common goals stated in the Declaration of Bangkok 1967 and guided by the Treaty of Amity and Cooperation (TAC) 1976. In addition to that, inclusivity or inclusiveness is an accepted criterion by all ASEAN member-states and its dialogue partners since ASEAN has a lot of extra-regional fora such as ADMM+, ASEAN+, and many more agreements that involve not only its members but also external countries worldwide. Therefore, it is no wonder when ASEAN wants those norms in its concept of Indo-Pacific to make it in line with ASEAN point of view, in which many parties, including the US, have signed ASEAN's TAC. The consistency set up by ASEAN, in fact, has strengthened its stand on the concept of Indo-Pacific in comparison with any other proposal on the issue.

Having been encountered by the competition of power between the US and China 
which provides uncertainty as well as opportunity, ASEAN should contain those powers' concern so that its position in the region is safe and profitable to its members. Hedging approach in which ASEAN is taking position neither on side nor against another, is a realistic option to be prefered by since the outcome of the competition is not concluded yet. ASEAN flexibility reflected in its more than half-decade experience in dealing with uncertainties, just like that of the Cold War period, has given a valuable lesson to ASEAN to play safe as always. From here on, one would be more convinced to see how ASEAN turn its shorthandedness of its member's national limited ability to advantage in rationalizing hedging strategy in the case of US-China competition over the region. It is true that today, the US has one step ahead to developing-China but, none is sure what the future holds. With its potential as well as consistent growth, China might be a competent rival for the US in decades ahead. Even though it does not fix the contestation between the US and China, hedging does buy some time for all actors, especially that of under ASEAN platform, to come out with the common certain strategy and without jeopardizing current ASEAN member-states national interests.

\section{Conclusion}

The emergence of China as a revisionist state around the region of Indo-Pacific has had diverse responses from global actors. The US sees China as a challenger to its global hegemon. On the other hand, ASEAN considers the competition between those powers as an opportunity to bolster its member-states national development while, in fact, they also suffer from some problems out of it to some extent. The conception of Indo-Pacific cooperation framework which is open to any interpretation, besides its reference to a certain area around the Indian and the Pacific Oceans, has provided both ASEAN and the US an opportunity to formulize a regional motion according to their respective strategic regional assessment. With its global interests, the US exercises balancing approach to deal with Chinese aggressivity in order to maintain its dominance over the region of Indo-Pacific. On the other hand, ASEAN conducts hedging in its attempt to conceptualize the term Indo-Pacific cooperative architecture so that they are disposed of safely in approaching the US as well as China. The diverse approaches by both actors reflect their different interests and perceptions of the threat contained in the rise of China.

\section{References}

\section{Book \& Book Chapter}

Lamont, Christopher, 2015. Research methods in international relations. London: SAGE Publication.

Mearsheimer, J.J., 2001. The Tragedy of Great Power Politics. New York: WW Norton \& Company.

Mowle, T. and Sacko, D., 2007. The Unipolar World: An Unbalanced Future. Berlin: Springer. 
Platias, A.G. and Konstantinos Koliopoulos, 2010. Thucydides on Strategy: Grand Strategies in the Pelopennesian War and Their Relevance Today. New York: Columbia University Press.

Tziampiris, A., 2015. The Emergence of Israeli-Greek Cooperation. Cham: Springer.

Walt, S.M., 1990. The Origins of Alliance. New York: Cornell University Press.

Waltz, K.N., 1979. Theory of international politics. California: Addison-Wesley Publishing Company.

Yan, Jinny, 2018. "The Belt and Road Initiative in Southeast Asia.” In Michael Cox et al. China's Belt and Road Initiative (BRI) and Southeast Asia. Kuala Lumpur: CIMB Southeast Asia Research Sdn Bhd.

\section{Journal and Online Journal}

Art, R.J., 2006. “Striking the balance”, International security, 30(3): 177-185.

Brooks, S. G. and William C. Wohlforth, 2005. "Hard times for soft balancing", International security, 30(1): 72-108.

He, Kai. and Huiyung Feng, 2008. "If not soft balancing, then what? Reconsidering soft balancing and US policy toward China”, Security Studies, 17(2): 363-395.

Healy, B. and Arthur Stein, 1973. "The balance of power in international history: theory and reality", Journal of Conflict Resolution, 17(1): 33-61.

Hou, J., et al, 2018. "Measuring the Benefits of the "One Belt, One Road” Initiative for Manufacturing Industries in China”, Sustainability, 10(12): 4717.

Koga, K., 2017. “The concept of "hedging” revisited: the case of Japan's foreign policy strategy in East Asia's power shift”, International Studies Review, 20(4): 633660.

Lake, D.A., 1996. "Anarchy, hierarchy, and the variety of international relations”, International organization, 50(1): 1-33.

Lieber, K.A. and G. Alexander, 2005. "Waiting for balancing: Why the world is not pushing back”, International Security, 30(1): 109-139.

Nexon, D.H., 2009. "The Balance of Power in The Balance", World Politics, 61(2): 330-359.

Pape, R.A., 2005. "Soft balancing against the United States", International security, 30(1): 7-45.

Putra, B., 2015. "Indonesia's Leadership Role in ASEAN: History and Future Prospects”, International E-Journal of Advances in Social Sciences, 1(2): 188197. 
Suryadinata, Leo, 2018. "Indonesia and Its Stance on the "Indo-Pacific"”, ISEAS Perspective, October, 66: 1-7.

\section{Government Official Publication}

National Security Strategy of the United States of America, 2017. Washington DC: White House

\section{Annual Report}

Organsation for Economic Co-operation and Development (OECD), 2019. 2019 FDI in Figures.

United Nations Conference on Trade and Development (UNCTAD), 2016. Review of Maritime Transport 2016.

\section{Online Article}

Amadeo, Kimberly, 2019. "China's Economic Growth, Its Causes, Pros, Cons, and Future" [online]. in https://www.thebalance.com/china-s-economic-growthcause-pros-cons-future-3305478. [Accessed 9 August 2019].

Asian Infrastructure Investment Bank, 2019. "Introduction" [Online] in https://www. aiib.org/en/about-aiib/index.html [Accessed on 9 August 2019].

BBC, 2016. "Why Is South China Sea Contentious?”, July 12, [onine]. in https://www. bbc.com/news/world-asia-pacific-13748349 [accessed 9 August 2019].

Bodeen, Christopher, 2019. "Why a Chinese Officer Said South China Sea Island Fortification is Driven by 'Threats”, NavyTimes, January 9, [online] in https:// www.navytimes.com/news/your-navy/2019/01/o9/why-a-chinese-officer-saidsouth-china-sea-island-fortification-is-driven-by-threats/ [accessed 9 August 2019].

Cha, Victor, 2016. "The Unfinished Legacy of Obama's Pivot to Asia”, Foreign Policy, September 6 [online]. in https://foreignpolicy.com/2016/og/o6/theunfinished-legacy-of-obamas-pivot-to-asia/ [accessed 12 March 2019].

CSIS, China Power Project, 2019a. "Does China dominate global investment?” [online]. in https://chinapower.csis.org/china-foreign-direct-investment/ [accessed 9 August 2019].

CSIS, China Power Project, 2019b. "How Much Trade Transits the South China Sea?", [Online]. in https://chinapower.csis.org/much-trade-transits-south-chinasea/\# easy-footnote-bottom-1-3073 [accessed 9 August 2019]. 
Ewing, Jack, 2018. "Europe and U.S. Agree on Chinese Threat, but Are Too Busy Feuding to Fight It”, The New York Times, December 7, [online]. in https:// www.nytimes.com/2018/12/07/business/european-union-trump-china-trade. html [accessed 9 August 2019].

Gallu, Joshua, and David Tweed, 2018. “Trump’s Asia Summit Snub Fuels Doubts About U.S. Commitment”. Bloomberg, September 3, [online]. in https://www. bloomberg.com/news/articles/2018-09-03/trump-s-asia-summit-snub-fuelsdoubts-about-u-s-commitment [accessed 12 March 2019].

Garekar, Bhagyashree, 2018. "ASEAN Wants to Work with Both US and China, Says PM Lee, as Pence Calls for Indo-Pacific free of 'Empires", Strait Times, November 15 [online]. in https://www.straitstimes.com/singapore/us-vice-presidentpence-says-empire-and-aggression-have-no-place-in-indo-pacific [accessed 6 February 2019].

Jha, Lalit K, 2019. "Trump Proposes USD 1 billion to Advance Free and Open IndoPacific", Outlook India, March 12 [online]. in https://www.outlookindia. com/newsscroll/trump-proposes-usd-1-billion-to-advance-free-and-openindopacific/1494494 [accessed 12 March 2019].

Kelkar, Keshav, 2018. “A Fragmented Picture of the New World Order” [online]. in https://www.policyforum.net/a-fragmented-picture-of-the-new-world-order/ [accessed 9 August 2019].

Khurana, Gurpreet Singh, 2017. "The Indo-Pacific Concept: Retrospect and Prospect" [online]. in http://cimsec.org/indo-pacific-concept-retrospect-prospect/34710 [accessed 4 February 2019].

Kuo, Mercy A, 2018. "The Origin of 'Indo-Pacific' as Geopolitical Construct”, The Diplomat, January 25, [online]. in https://thediplomat.com/2018/01/theorigin-of-indo-pacific-as-geopolitical-construct/ [accessed on 5 February 5, 2019).

Kurmala, Aziz and Bayu Prasetyo, 2018. "ASEAN Expected to Adopt Indo-Pacific Concept in 2019", Antara, November 18, [online]. in https://en.antaranews. com/news/120565/asean-expected-to-adopt-indo-pacific-concept-in-2019 [Accessed 13 March 2019].

Laksmana, Evan A, 2018. "Buck-Passing from Behind: Indonesia's Foreign Policy and the Indo-Pacific" [online]. in https://www.brookings.edu/blog/order-fromchaos/2018/11/27/buck-passing-from-behind-indonesias-foreign-policy-andthe-indo-pacific/ [accessed 6 February 2019].

Laksmana, Evan A, 2018b. "Indonesia's Indo-Pacific Vision is A Call for ASEAN to Stick Together Instead of Picking Sides", South China Morning Post, November 20, [online]. in https://www.scmp.com/week-asia/geopolitics/article/2173934/ indonesias-indo-pacific-vision-call-asean-stick-together [accessed 6 February 2019]. 
Nathalia, Telly, 2018. "Indonesia Presents Indo-Pacific Cooperation Concept at Asean Ministerial Meeting”, Jakarta Globe, August 2, [online]. in https://jakartaglobe. id/context/indonesia-conveys-indo-pacific-concept-asean-meetings [accessed 6 February 2019].

Ng, Edward, 2017. "The Rise of Chinese FDI into ASEAN." [Online]. in https:// en.nikkoam.com/articles/2017/10/the-rise-of-chinese-fdi-into-asean [accessed 8 August 2019].

Peña, Charles V, 2018. "How Real Is the Chinese Threat to the United States?", The Diplomat, August 24, [online]. in https://thediplomat.com/2018/08/how-realis-the-chinese-threat-to-the-united-states/ [accessed 9 August 2019].

Phillips, Tom et al., 2016. "Beijing Rejects Tribunal's Ruling in South China Sea Case", The Guardian, July 12, [online] in https://www.theguardian.com/world/2016/ jul/12/philippines-wins-south-china-sea-case-against-china [accessed 9 August 2019].

Phillips, Tom, 2016. "China Attacks International Court after South China Sea Ruling”, The Guardian, July 13 [online]. in https://www.theguardian.com/world/2016/ jul/13/china-damns-international-court-after-south-china-sea-slapdown [accessed on 9 August 2019].

Phillips, Tom, 2018. "Photos Show Beijing's Militarisation of South China Sea in New Detail", The Guardian, February 6 [online]. in https://www.theguardian. com/world/2018/feb/06/photos-beijings-militarisation-south-china-seaphilippines [accessed 5 February 2019].

Saiman, Arif and Endy M. Bayuni, 2018. "Time for Asean to Drive the Indo-Pacific Process: Jakarta Post Writers". Strait Times, November 7, [online]. in https:// www.straitstimes.com/asia/se-asia/time-for-asean-to-drive-the-indo-pacificprocess-jakarta-post-writers [accessed 6 February 2019].

Samaan, Jean Loup, 2019. "Confronting the Flaws in America's Indo-Pacific Strategy", War on the Rocks, February 11, [online]. in https://warontherocks.com/2019/02/ confronting-the-flaws-in-americas-indo-pacific-strategy/ [accessed 12 March 2019].

Statista, 2018a. "ASEAN Countries: GDP Per Capita from 2008 to 2018 (in U.S. Dollars)”. [Online] in https://www.statista.com/statistics/804307/grossdomestic-product-gdp-per-capita-in-the-asean-countries/ [Accessed 9 August 2019].

Statista, 2018b. "The 20 Countries with The Largest Gross Domestic Product (GDP) Per Capita in 2017 (in U.S. Dollars)". [Online] in https://www.statista.com/ statistics/270180/countries-with-the-largest-gross-domestic-product-gdp-percapita/ [Accessed 9 August 2019]

Statista, 2019a. "China: Export of Goods from 2007 to 2017 (in Billion U.S. Dollars)". [Online] in https://www.statista.com/statistics/263661/export-of-goods-from- 
china/ [Accessed 9 August 2019].

Statista, 2019b. "Total Volume of U.S. Exports of Trade Goods from 1987 to 2017 (in Billion U.S. Dollars)". [Online] in https://www.statista.com/statistics/186577/ volume-of-us-exports-of-trade-goods-to-the-world-since-1987/ [Accessed 9 August 2019]

Steward, Cameron, 2018. "Pompeo Commits US to Indo-Pacific." [online]. in https:// www.atlanticcouncil.org/blogs/new-atlanticist/pompeo-s-indo-pacificinvestment-plan/ [accessed 12 March 2019].

The World Bank, 2018. "The World Bank in China", [online]. in https://www. worldbank.org/en/country/china/overview [accessed 9 August 2019].

Trading Economics, 2019. "China GDP Annual Growth Rate”, [online]. in https:// tradingeconomics.com/china/gdp-growth-annual [accessed 9 August 2019].

\section{Others}

Kizekova, A., 2013. Soft balancing in the Indo-Asia-Pacific: complexity, threat and contending multilateral frameworks from ASEAN to the SCO. Doctoral dissertation. Robina: Faculty of Humanities and Social Sciences Bond University.

Salman, M. and Gustaaf Geeraerts, 2013. "The impact of strategic hedging on the foreign politics of great powers: the case of Chinese energy strategy in the Middle East”. In China Goes Global Conference. Bremen: Jacobs University Bremen (pp. 25-27).

Rozman, G. and Chen Chwee Kuik, 2015. "Light or Heavy Hedging: Positioning Between China and the United States”, Joint US-Korea Academic Studies, 26: 1-9. 